\title{
Probabilistic storm surge inundation maps for Metro Manila based on Philippine public storm warning signals
}

\author{
J. Tablazon ${ }^{1,3}$, C. V. Caro ${ }^{1}$, A. M. F. Lagmay ${ }^{1,2}$, J. B. L. Briones ${ }^{1}$, L. Dasallas ${ }^{1}$, J. P. Lapidez ${ }^{1}$, J. Santiago ${ }^{1,4}$, \\ J. K. Suarez ${ }^{1}$, C. Ladiero $^{1}$, L. A. Gonzalo ${ }^{1}$, M. T. F. Mungcal ${ }^{1}$, and V. Malano ${ }^{5}$ \\ ${ }^{1}$ Nationwide Operational Assessment of Hazards, Quezon City, Philippines \\ ${ }^{2}$ National Institute of Geological Sciences, University of the Philippines Diliman, Quezon City, Philippines \\ ${ }^{3}$ Institute of Environmental Science and Meteorology, University of the Philippines Diliman, Quezon City, Philippines \\ ${ }^{4}$ School of Urban and Regional Planning, University of the Philippines Diliman, Quezon City, Philippines \\ ${ }^{5}$ Philippine Atmospheric, Geophysical and Astronomical Services Administration, Quezon City, Philippines \\ Correspondence to: J. Tablazon (jptablazon@ noah.dost.gov.ph)
}

Received: 15 August 2014 - Published in Nat. Hazards Earth Syst. Sci. Discuss.: 1 October 2014

Revised: 10 February 2015 - Accepted: 19 February 2015 - Published: 12 March 2015

\begin{abstract}
A storm surge is the sudden rise of sea water over the astronomical tides, generated by an approaching storm. This event poses a major threat to the Philippine coastal areas, as manifested by Typhoon Haiyan on 8 November 2013. This hydro-meteorological hazard is one of the main reasons for the high number of casualties due to the typhoon, with 6300 deaths. It became evident that the need to develop a storm surge inundation map is of utmost importance. To develop these maps, the Nationwide Operational Assessment of Hazards under the Department of Science and Technology (DOST-Project NOAH) simulated historical tropical cyclones that entered the Philippine Area of Responsibility. The Japan Meteorological Agency storm surge model was used to simulate storm surge heights. The frequency distribution of the maximum storm surge heights was calculated using simulation results of tropical cyclones under a specific public storm warning signal (PSWS) that passed through a particular coastal area. This determines the storm surge height corresponding to a given probability of occurrence. The storm surge heights from the model were added to the maximum astronomical tide data from WXTide software. The team then created maps of inundation for a specific PSWS using the probability of exceedance derived from the frequency distribution. Buildings and other structures were assigned a probability of exceedance depending on their occupancy category, i.e., $1 \%$ probability of exceedance for critical facilities, $10 \%$ probability of exceedance for special occupancy structures, and $25 \%$ for standard occupancy and miscellaneous struc-
\end{abstract}

tures. The maps produced show the storm-surge-vulnerable areas in Metro Manila, illustrated by the flood depth of up to $4 \mathrm{~m}$ and extent of up to $6.5 \mathrm{~km}$ from the coastline. This information can help local government units in developing early warning systems, disaster preparedness and mitigation plans, vulnerability assessments, risk-sensitive land use plans, shoreline defense efforts, and coastal protection measures. These maps can also determine the best areas to build critical structures, or at least determine the level of protection of these structures should they be built in hazard areas. Moreover, these will support the local government units' mandate to raise public awareness, disseminate information about storm surge hazards, and implement appropriate countermeasures for a given PSWS.

\section{Introduction}

\subsection{Background}

The National Oceanic and Atmospheric Administration (NOAA) defines a storm surge as a storm-generated abnormal rise of water over the predicted astronomical tides. Storm surges are complex phenomena due to their dependence on the slightest changes in the tropical cyclones' parameters. These variables include central atmospheric pressure, wind intensity, storm size, storm forward speed, angle of approach to coast, shape of the coastline, width and slope of the ocean bottom, and local features. Higher storm surges 
Table 1. Public storm warning signals from PAGASA.

\begin{tabular}{ll}
\hline PSWS \# 1 & $\begin{array}{l}\text { Winds of 30-60 kph (16-32 kn) may be expected in } \\
\text { at least } 36 \mathrm{~h}\end{array}$ \\
PSWS \# 2 & $\begin{array}{l}\text { Winds of greater than } 60 \mathrm{kph}(32 \mathrm{kn}) \text { and up to } \\
100 \mathrm{kph}(54 \mathrm{kn}) \text { may be expected in at least } 24 \mathrm{~h}\end{array}$ \\
PSWS \# 3 & $\begin{array}{l}\text { Winds of greater than } 100 \mathrm{kph}(54 \mathrm{kn}) \text { up to } 185 \mathrm{kph} \\
(100 \mathrm{kn}) \text { may be expected in at least } 18 \mathrm{~h}\end{array}$ \\
PSWS \# 4 & $\begin{array}{l}\text { Very strong winds of more than } 185 \mathrm{kph}(100 \mathrm{kn}) \\
\text { may be expected in at least } 12 \mathrm{~h}\end{array}$ \\
\hline
\end{tabular}

can be observed for an approaching tropical cyclone with lower central atmospheric pressure, stronger winds, larger storm size, angle that is perpendicular to the coastlines, faster translational speed on open coast, slower typhoon on enclosed bodies of water, gently sloping continental shelves, and the absence of natural or artificial coast barriers to impede the flow of sea water.

Storm surges result in more damaging flood conditions in coastal zones and adjoining low-lying areas (Dasgupta, 2009). According to the Coastal Services Center of NOAA, flooding or inundation is among the more frequent, costly, and deadly hazards that can impact coastal communities. Storm surges are a major threat to the Philippine coastal areas, as manifested by Typhoon Haiyan (Fig. 1) on 8 November 2013. This hydro-meteorological hazard is one of the main reasons for the high number of casualties due to the typhoon, with 6300 deaths, 1061 missing, and damages estimated at USD 2 billion (National Disaster Risk Reduction and Management Council, 2014).

Tropical cyclones are known to form in the tropical regions, such as northern Australia, Southeast Asia, and other Pacific islands. The warm waters near the equator serve as the driving force to develop the tropical cyclones. Located in the southwestern region of the Pacific Ocean, the Philippines is geographically prone to tropical cyclones (Fig. 2). According to the Philippine Atmospheric, Geophysical, and Astronomical Services Administration (PAGASA, 2014a), an average of 20 tropical cyclones enter the Philippine Area of Responsibility (PAR) per year, nine of which make landfall. In addition, the country's coastlines are low-elevation coastal zones (LECZ) wherein $9.54 \%$ of the coastal municipalities and cities are $10 \mathrm{~m}$ or below based on GIS-derived SRTM data. McGranahan et al. (2007) define LECZ as the contiguous area along the coast that is less than $10 \mathrm{~m}$ a.s.l. Low elevation and the frequent onslaught of tropical cyclones are the major reasons that the country is vulnerable to storm surge events.

\subsection{Objective}

In light of the recent disasters that the country has experienced, the Department of Science and Technology (DOST) funded a project wherein a multidisciplinary approach to developing systems, tools, and other technologies helping to prevent and mitigate disasters was launched. This project is called the Nationwide Operational Assessment of Hazards (Project NOAH). Project NOAH, together with PAGASA, the country's national meteorological institution, spearheaded a study to create inundation maps to mitigate impacts of storm surge events. The objective of this study is to develop storm surge inundation maps using simulations of historical tropical cyclones and their associated public storm warning signal (PSWS).

\subsection{Public storm warning signal}

The PSWS is issued by PAGASA to provide warning to the public of incoming weather disturbances. As shown in Table 1, these signals are raised when tropical cyclones are expected to enter the PAR and may also be upgraded or downgraded depending on the strength and proximity of the tropical cyclone. When a PSWS is raised, the meteorological conditions are not yet prevailing over the area since its main purpose is to warn the public of the impending effects that the tropical cyclone would bring. The PSWS given to a certain region is based on the intensity, size of circulation, forecast direction, and speed of the tropical cyclone (PAGASA, 2014b).

\subsection{Limitations}

It is important to note that this study is based on the PSWS issued by PAGASA; storm signals are forecasted wind speeds and may not be accurate. This study is also limited to the number of tropical cyclones that fall on every PSWS and the number of events with storm surge height associated with every PSWS.

\subsection{Study area}

Metro Manila, including Meycauayan and Obando in Bulacan, was used for this study. It was selected for its high population density and its vulnerability to storm surges, given that it is frequented by tropical cyclones and $27 \%$ of Metro Manila is under the $10 \mathrm{~m} \mathrm{LECZ} \mathrm{(Fig.} \mathrm{3).}$

\section{Methodology}

\subsection{Storm surge modeling}

The Japan Meteorological Agency (JMA) storm surge model is a numerical code that is used to simulate and predict storm surges generated by tropical cyclones (Higaki, 2006). The numerical scheme of the model is based on two-dimensional shallow water equations. Other governing equations include the equation of motion and the continuity equation with air pressure and wind fields used as external forcings.

The storm surge model uses storm track, bathymetric data, central atmospheric pressure, and maximum wind speed as input parameters for the model. 


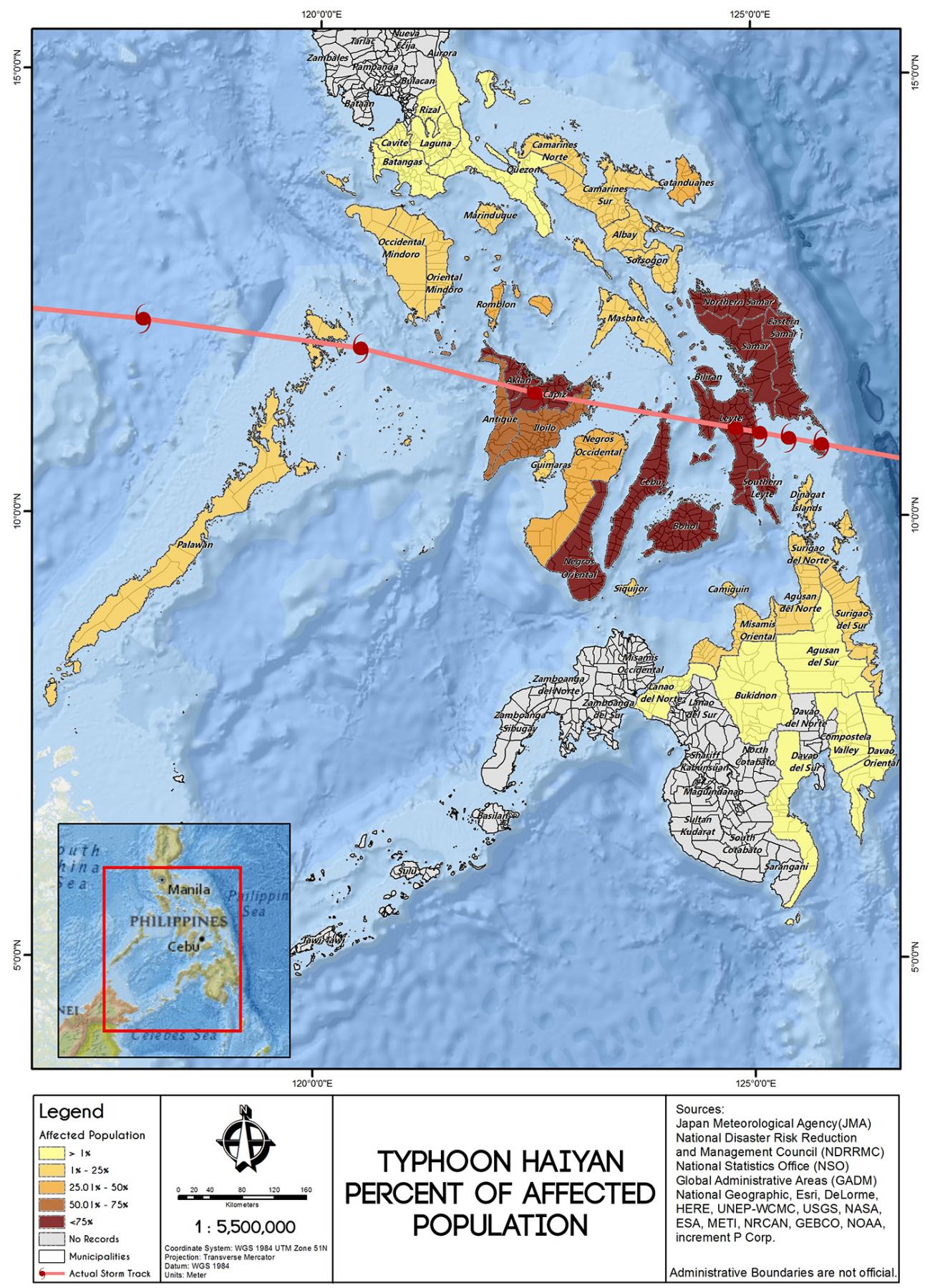

Figure 1. Typhoon Haiyan: percent of affected population (Project NOAH).

The bathymetric data used were 2 min gridded elevation data (ETOPO2). Tropical cyclone best track data from the Tokyo Typhoon Center of the Regional Specialized Meteorological Center were obtained from the JMA website. JMA releases tropical cyclone forecasts every $3 \mathrm{~h}$ and can be accessed for free on their site. The best track data text files contain the latitude and longitude of the center, central pres- sure $(\mathrm{hPa})$, maximum sustained wind speed (knots), and the radius of 50 and $30 \mathrm{kn}$ winds.

\subsection{Tide data}

This study used values for the astronomical tide derived from WXTide, a software containing archives/catalogues of worldwide astronomical tides (WXTide32, 2014). WXTide 


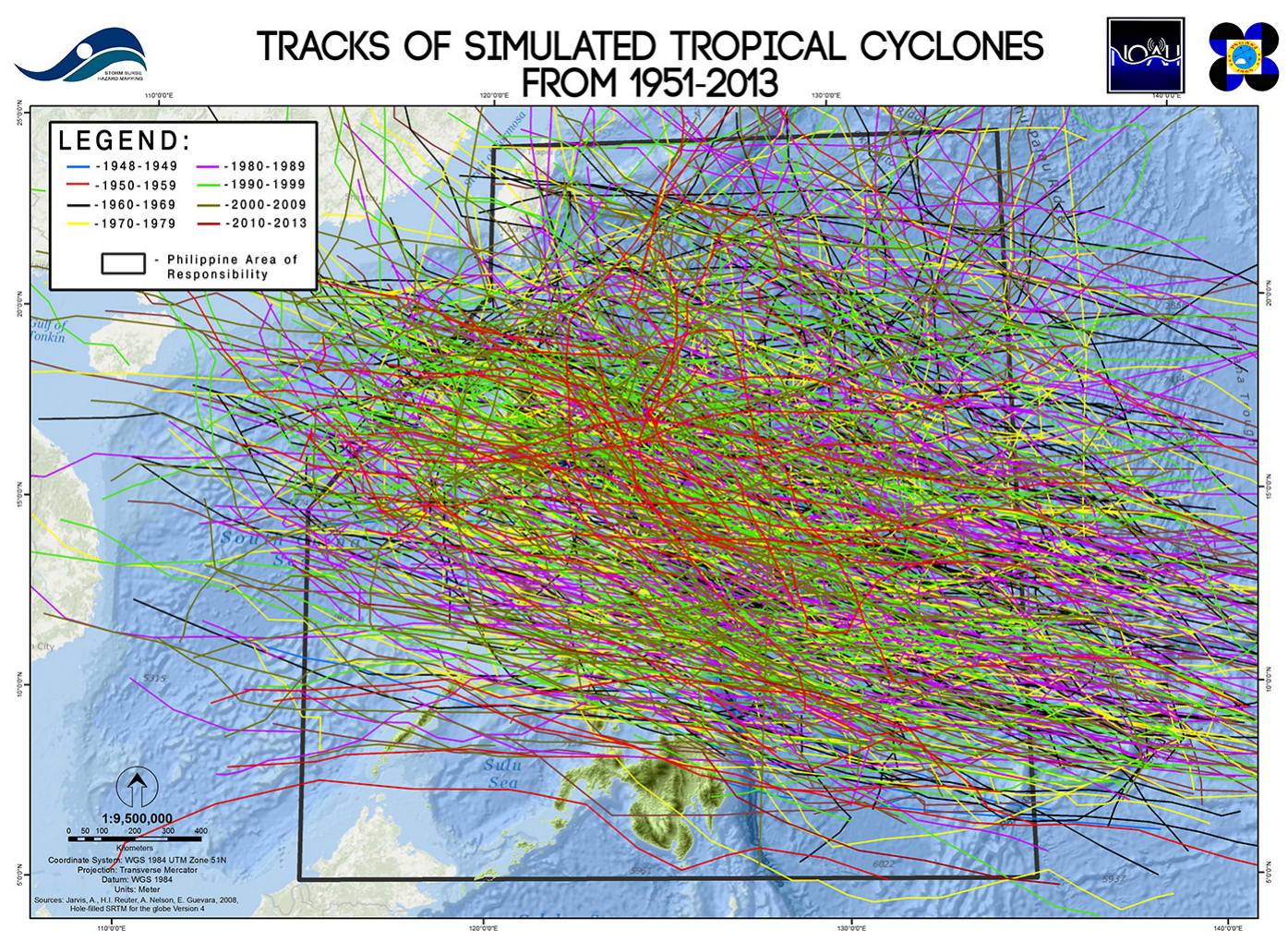

Figure 2. Tracks of tropical cyclones that entered the Philippine Area of Responsibility from 1951 to 2013 (Project NOAH).

predicts tide levels from 1970 through 2037. It produces text outputs of the daily tide list, monthly calendar, and incremental tide. It also generates BMP graphics and text tide CSV spreadsheet files. WXTide has records of worldwide time zones and solar or lunar events. The software can save recent stations and real-time tide states.

\subsection{Flood modeling}

The proponents of this study used FLO-2D, a grid developer system software that has maps with topographies and creates models based on the grid topographies, boundaries, and tides. This software is used in river studies and unconfined flood analyses and is approved by the Federal Emergency Management Agency of the United States of America. FLO2D is a combined hydrologic and hydraulic model (FLO-2D Software, 2014). The software integrates river and floodplain flood routing. The following data are required for FLO-2D to simulate the flow of water: digital terrain model (bare earth) data at $5 \mathrm{~m}$ resolution, hydrologic data (including rainfall and discharge hydrographs), and floodplain and channel detail. It also takes into account various parameters and detail features, such as surface roughness, street flow, presence of walls and levees, hydraulic structures, vegetation, and soil type.

To simulate an inundation output using FLO-2D, the input data wave height (water level elevation) as a function of time for the coastal grid element is required (US IOTWS, 2007). This water level height is one of the outputs produced by the JMA storm surge model. The time series charts provided by each of the JMA model observation points were plotted into its corresponding shorelines, creating a base water level elevation necessary for FLO-2D inundation. Time series charts were adjusted to incorporate the tide data derived using WXTide.

\subsection{Probability of exceedance}

The storm surge numerical models greatly depend on the accuracy of the forecast of a tropical cyclone's track, size, and intensity. Forecasting the storm surge height and time series with $100 \%$ precision is particularly difficult since even the best tropical cyclone forecasts still have considerable uncertainty.

The exceedance probability curve gives the forecast probability that a particular parameter quantity will be exceeded at the location in question for a given season and time (NOAA, 2012). This graphical representation describes the probability that some various levels of loss will be exceeded over a future time period or will be surpassed over a given time (Grossi and Kunreuther, 2005). Forecast curves also show the percentage anomaly of the most favored tercile of the climatological distribution: below normal, near normal, and above normal. 


\section{$10 \mathrm{~m}$ low-elevation coastal zone in Metro Manila}

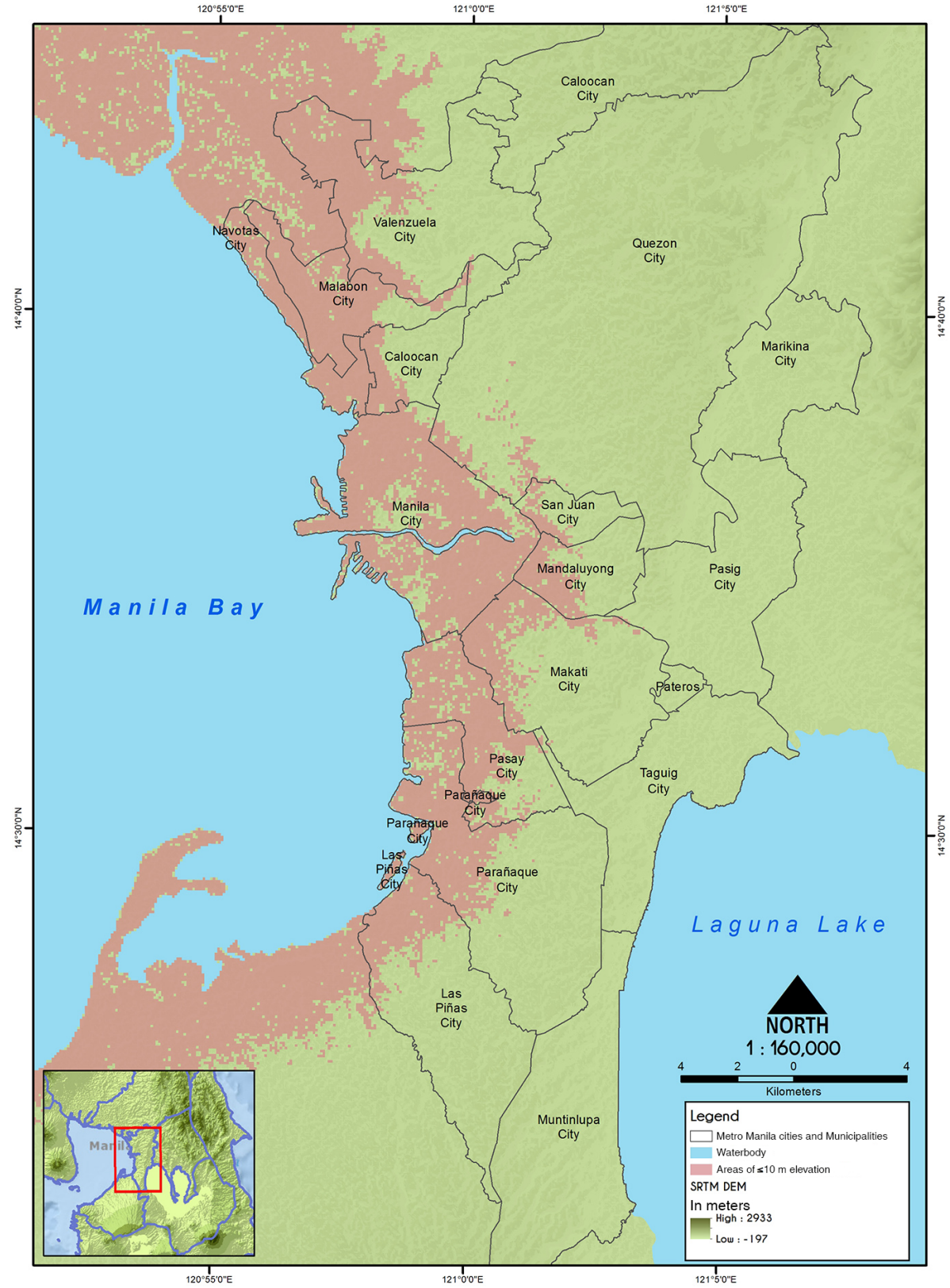

Figure 3. $10 \mathrm{~m}$ low-elevation coastal zone in Metro Manila.

The storm surge time series generated by tropical cyclones were categorized according to the PSWS released when the tropical cyclone passed a certain area. Each PSWS is grouped in terms of the maximum sustained winds of the tropical cyclones. Of all the storm surge time series plotted by historical tropical cyclones' PSWS since 1971, it is difficult to select which actual typhoon-induced storm surge time series is likely to behave the same as the tropical cyclone to be forecasted.

To find the most accurate solution, the researchers used the probability of exceedance to evaluate the storm surge time series curves. For each region, the PSWS released for the tropical cyclones that affected the aforesaid region were categorized in order to determine the storm surge time series. The storm surge time series gives the change in storm surge height for each tropical cyclone. The tropical cyclones that produced the highest storm surge can be observed in this probability curves. The percentage of the exceedance curve determines the probability of a certain tropical cycloneinduced storm surge to behave within a certain exceedance range. A tropical cyclone with $1 \%$ exceedance probability would produce a storm surge of greater intensity than 
Table 2. Classification of structures and nature of occupancy (ASEP, 2010).

\begin{tabular}{|c|c|}
\hline Occupancy category & Occupancy or function of structure \\
\hline I - essential facilities & $\begin{array}{l}\text { Occupancies having surgery and emergency treatment areas, fire and police stations, garages } \\
\text { and shelters for emergency vehicles and emergency aircraft; structures and shelters in emer- } \\
\text { gency preparedness centers; aviation control towers; structures and equipment in communica- } \\
\text { tion centers and other facilities required for emergency response; facilities for standby power- } \\
\text { generating equipment for category I structures; tanks and other structures housing or supporting } \\
\text { water or other fire-suppression material or equipment required for the protection of category I, } \\
\text { II, or III structures; public school buildings, hospitals, and designated evacuation centers. }\end{array}$ \\
\hline II - hazardous facilities & $\begin{array}{l}\text { Occupancies and structures housing or supporting toxic or explosive chemicals or substances; } \\
\text { non-building structures storing, supporting, or containing quantities of toxic or explosive sub- } \\
\text { stances. }\end{array}$ \\
\hline III - special occupancy structures & $\begin{array}{l}\text { Single-story school buildings; buildings with an assembly room with an occupant capacity of } \\
1000 \text { or more; educational buildings such as museums and libraries; auditoriums with a capacity } \\
\text { of } 300 \text { or more students; buildings used for college or adult education with a capacity of } 500 \text { or } \\
\text { more students; institutional buildings with } 50 \text { or more incapacitated patients but not included } \\
\text { in category I; mental hospitals, sanatoriums, jails, prisons, and other buildings where personal } \\
\text { liberties of inmates are similarly restrained; all structures with an occupancy of } 5000 \text { or more } \\
\text { persons; structures and equipment in power-generating stations; and other public utility facilities } \\
\text { not included in categories I or II and required for continued operation. }\end{array}$ \\
\hline IV - standard occupancy structures & All structures housing occupancies or having functions not listed in categories I, II, III, and V. \\
\hline V - miscellaneous structures & Private garages, carports, sheds, and fences over $1.5 \mathrm{~m}$ high. \\
\hline
\end{tabular}

Table 3. Assigned probability of exceedance for every occupancy category.

\begin{tabular}{ll}
\hline Probability of exceedance & Occupancy category \\
\hline $1 \%$ & Essential facilities \\
& Hazardous facilities \\
$10 \%$ & Special occupancy structures \\
$25 \%$ & Standard occupancy structures \\
& Miscellaneous structures \\
\hline
\end{tabular}

those storm surges produced from other historical tropical cyclones.

\subsection{Nature of occupancy and probability of exceedance}

The corresponding probabilities of exceedance were determined based on the classification of structures by nature of occupancy from the National Structural Code of the Philippines (Table 2).

To take into account the storm surge heights that will be used for the flood modeling, the researchers specified 1, 10, and $25 \%$ probability of exceedance (Table 3 ). Each probability corresponds to a particular storm surge height for every province in the Philippines and for every PSWS. The given probabilities were specified with consideration to the storm surge height difference between the height values of 1,10 , and $25 \%$.

\subsection{Process}

The JMA storm surge model was used to simulate 721 tropical cyclones that entered PAR and significantly affected Philippine weather. Best track data of all the tropical cyclones in the Northwestern Pacific basin from 1951 to 2013 were acquired from the JMA website.

A station file containing points specified by the user where the storm surge height will be computed is also needed. A total of 4996 observation points for the entire Philippines were identified. As shown in Fig. 4, 10 of these points were in Metro Manila.

The input files for the 721 tropical cyclones were run using the JMA storm surge model. These simulations produced time series plots of the storm surges produced by each tropical cyclone for all the observation points to determine the maximum storm surge height and time.

All PSWSs raised for each province in the Philippines from 1971 to 2013 were grouped according to storm signals 1, 2, 3, and 4. These data were grouped based on the maximum PSWS that hit a specific province. For Metro Manila, there were 143 tropical cyclones that reached PSWS 1, 46 for PSWS 2, 21 for PSWS 3, and 2 for PSWS 4 (Fig. 5). 


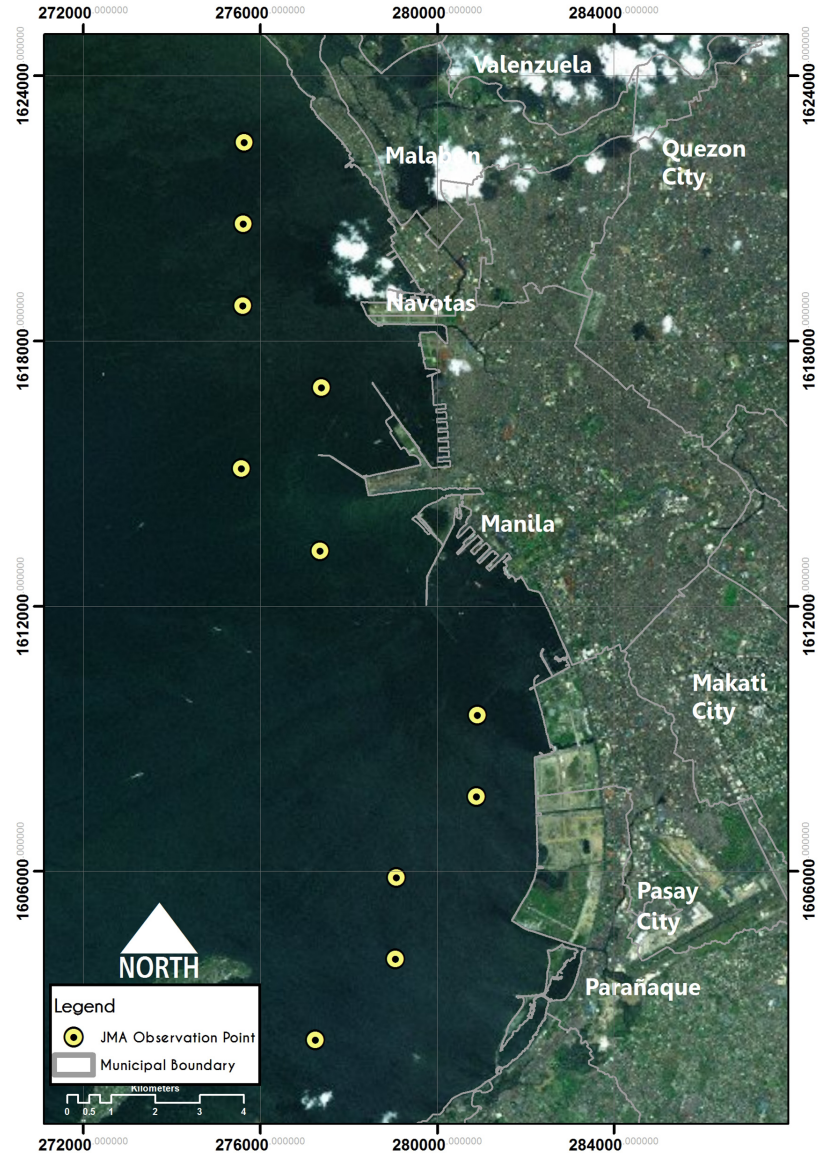

Figure 4. Specified observation points of Metro Manila.

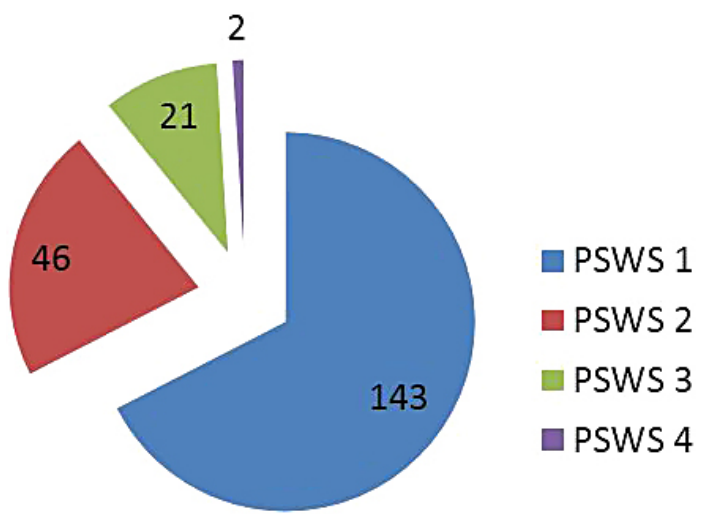

Figure 5. PSWS frequency distribution for Metro Manila.

For each PSWS, the maximum storm surge heights per tropical cyclone per observation point were tallied to create a frequency distribution table from which the probability of exceedance was derived. The probability of exceedance was determined by solving for the cumulative probability of the maximum heights for each PSWS. This method allowed the researchers to determine the probability that a certain storm surge height will be exceeded. All of the tropical cyclone

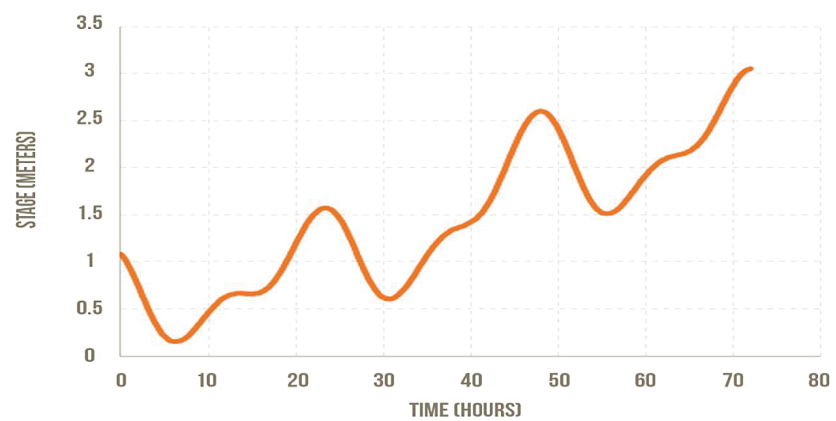

Figure 6. Example storm tide of Metro Manila.

time series with maximum storm surge height under the 1 , 10 , and $25 \%$ probability of exceedance were grouped together to create an averaged time series to be used as an input value for the FLO-2D.

Each time series plot of all the tropical cyclones that fall for each storm signal collected and was processed using the moving average smoothing method to produce HVT as input for FLO-2D. The moving average smoothing technique was used to create a single time series for each probability value under every PSWS category. Using this technique, each element of the time series is replaced by the simple average of $n$ surrounding elements, where $n$ is the width of the smoothing "window" (Box and Jenkins, 1976; Velleman and Hoaglin, 1981). The window width used was 20 time steps. The time series for each probability of exceedance was then converted to an HVT file, which is the input file for the FLO-2D. An HVT file contains the water level values to its corresponding time element. This study used a 10 min interval HVT file for its inundation simulation (Fig. 6).

Since the JMA storm surge model only accounts for the height of the storm surge and does not include tidal parameters, the WXTide tide level data for the various observation points around the Philippines were added to the results of the JMA storm surge simulations.

The tide height was incorporated into the time series storm surge height produced by the JMA storm surge model to become the base input for FLO-2D. Although it was the simplest method, discrepancies in the observed and the simulated results might be discerned since the tidal and storm surge interaction was not considered. Another study may be needed to investigate the relationship between the two, since a tide-surge interaction can influence the generation of higher harmonics and eddy formation in the current field (Lynge et al., 2013), which in turn might influence the result of the final height, and the inundation thereof, created using the flood model.

The data generated by the JMA storm surge model and by WXTide were run on FLO-2D to simulate the inundation level and extent from storm surge occurrences. 

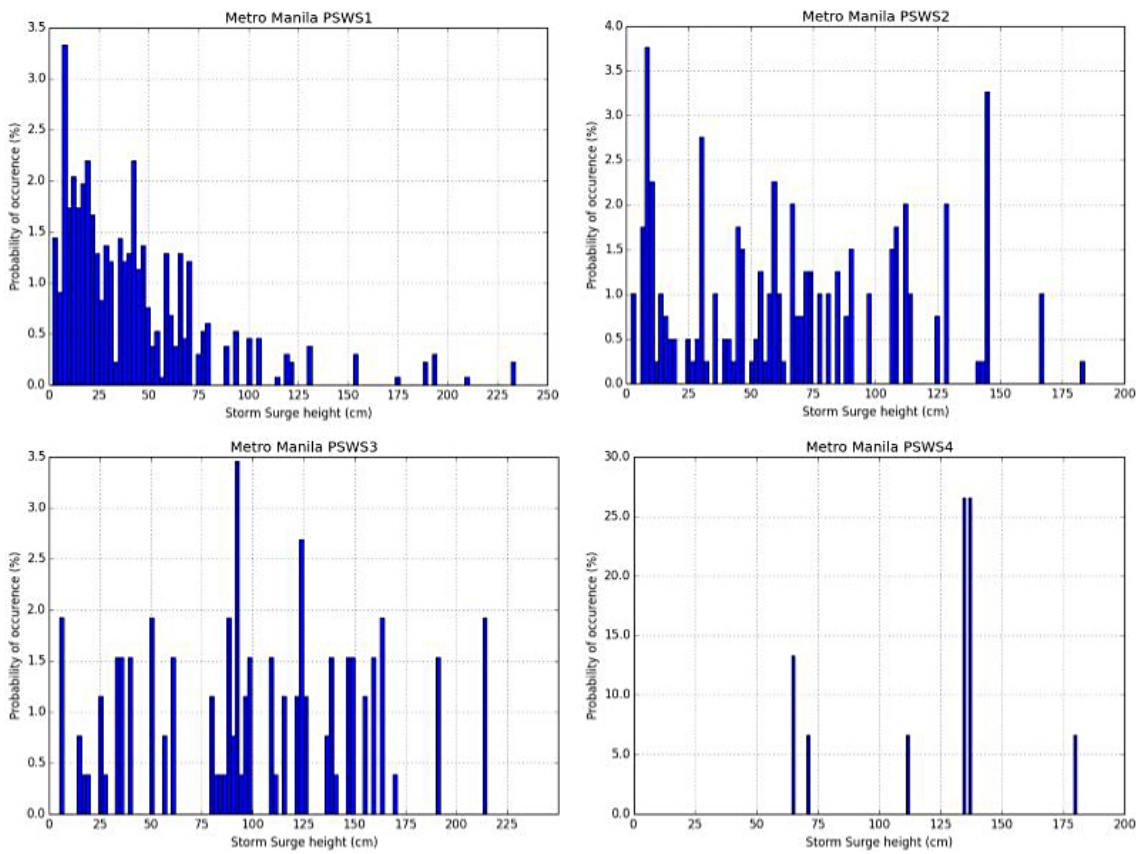

Figure 7. Frequency distribution table for PSWSs 1, 2, 3, and 4 of Metro Manila.

\section{Results and discussion}

To create a basis for drafting storm surge inundation maps in the Philippines, the researchers used a frequency distribution method and exceedance probability curves of the sorted PSWS and the time series produced by the JMA storm surge model.

The maximum storm surge height per tropical cyclone per observation point was tallied to create a frequency distribution table for PSWSs 1, 2, 3, and 4 of Metro Manila. This distribution of storm surge heights for each PSWS is illustrated in Fig. 7.

The exceedance probability distribution was derived from the frequency distribution. The graphical representation of the exceedance probability (Fig. 8) describes the probability that a particular storm surge height will be exceeded over a future time period or will be surpassed over a given time. The percentage of the exceedance curve determines the probability of a certain typhoon-induced storm surge to behave within a certain exceedance range. Each probability of exceedance has a corresponding storm surge height value.

Figures 9, 10, 11, and 12 illustrate the storm surge inundation maps per PSWS and per probability of exceedance. These maps show the varying extent of inundation depending on the probability of exceedance. As the percent of probability of exceedance increases, the extent of inundation decreases.

For PSWS 1 (Fig. 9) at $1 \%$ probability of exceedance Malabon, Manila, Navotas, and Obando are largely inundated, extending up to $6.5 \mathrm{~km}$ from the coast with flood depth reaching up to $3.01-4 \mathrm{~m}$. Some parts of Caloocan, Makati, and
Valenzuela are also inundated. For the $10 \%$ probability of exceedance, the same areas also extend up to $6.5 \mathrm{~km}$ but with shallower flood depth of mostly $1.01-2 \mathrm{~m}$. At $25 \%$ probability of exceedance, the maximum extent is up to $5.8 \mathrm{~km}$ covering the cities of Malabon, Navotas, and Obando with flood depths of mostly $1.01-2 \mathrm{~m}$.

For PSWS 2 (Fig. 10), 1, 10, and 25\% probability of exceedance inundates up to $5.9 \mathrm{~km}$ from the coast but with varying flood depths.

For PSWS 3 (Fig. 11) at $1 \%$ probability of exceedance, Malabon, Manila, Navotas, and Obando are greatly inundated, reaching up to $6 \mathrm{~km}$ from the coast with flood depth up to $3.01-4 \mathrm{~m}$. For the 10 and $25 \%$ probability of exceedance, inundation extends up to 5.9 and $5.7 \mathrm{~km}$, respectively, and inundates the same areas with flood depths reaching to 2.01$3 \mathrm{~m}$.

For PSWS 4 (Fig. 12) at 1 and $10 \%$ probability of exceedance, the extent of inundation reaches $6 \mathrm{~km}$ and covers large areas of Malabon, Manila, Obando, and Navotas but with different flood depths, reaching $3.01-4$ and $2.01-3 \mathrm{~m}$, respectively.

There is no corresponding map for PSWS 4 at $25 \%$ probability of exceedance. This can be attributed to the limited number of tropical cyclones that fall on PSWS 4. As mentioned in the introduction, the study is limited to the number of tropical cyclones that fall on every PSWS and the number of events with storm surge heights associated with each PSWS.

The results for PSWS 4 are inconclusive because of the low number of tropical cyclones that fell into this category 

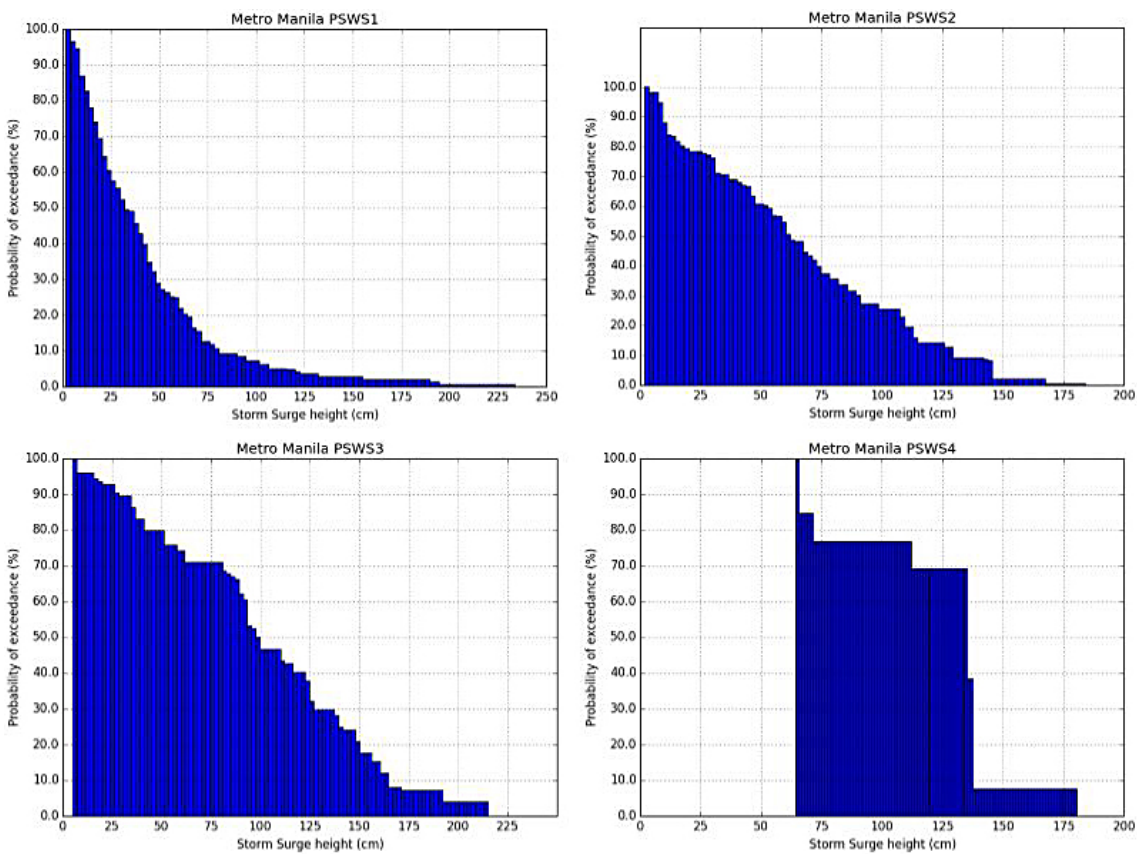

Figure 8. Exceedance probability curve for PSWSs 1, 2, 3, and 4 of Metro Manila.

during the time span covered in this study. Only two PSWS 4 tropical cyclones were raised in Metro Manila from 1971 to 2013. Hence, the probability of exceedance derived from this data set cannot be reliable. The result for PSWS 4 is simply insufficient to draw any meaningful conclusion.

It can be noted that PSWS 1 at $1 \%$ probability of exceedance has higher flood depths compared to that of PSWS 2. This is not to be expected, since higher PSWSs should produce higher storm surges. This can be attributed to the accuracy of the forecasts and the release of PSWSs by PAGASA. As mentioned in the limitations, it is important to note that PSWSs are forecasted wind speeds and may contain errors. It is possible that a PSWS 2 was released for Metro Manila, but the actual maximum sustained winds did not reach 60-100 kph.

Based on the assigned probability of exceedance for every occupancy category, essential facilities and hazardous facilities must be located in areas beyond the $1 \%$ probability of exceedance. On the other hand, special occupancy structures can be built beyond the $10 \%$ probability of exceedance and standard occupancy structures and miscellaneous structures can be located beyond the $25 \%$ probability of exceedance. It must be noted that the PSWS that recorded the highest flood depths must be used when planning where to build new structures.

The Philippine General Hospital is the largest hospital in the Philippines and is classified as an essential facility. As seen in Fig. 13, it is inundated at $1.07 \mathrm{~m}$ at PSWS 1 at $1 \%$ probability of exceedance. However, since the structure is al- ready built, appropriate engineering solutions must be done to ensure the safety of the people dependent on the structure.

Malacañang Palace is the official residence and principal workplace of the president of the Philippines. It is inundated at $1.06 \mathrm{~m}$ at PSWS 1 at $1 \%$ probability of exceedance. Port of Manila and Navotas Fish Port Complex, which are the major seaport and largest fish port in the country, are largely inundated at flood depths reaching up to 3.52 and $3.21 \mathrm{~m}$, respectively. These structures support the major economic activities of the Philippines and must be protected.

Barangays Bangkal in Makati, Tonsuya and Longos in Malabon, and North Bay Boulevard South in Navotas are some of the largest residential areas in Metro Manila and are classified as standard occupancy structures. Tonsuya and Longos have flood depths of 2.94 and $2.08 \mathrm{~m}$, respectively; Bangkal in Makati and North Bay Boulevard South in Navotas have flood depths of 2.26 and $2.54 \mathrm{~m}$, respectively. These structures are built inside the 1,10 , and $25 \%$ probability of exceedance areas of inundation. Thus, these structures must be retrofitted in order to ensure the safety of the people if storm surges with the same intensity is to be expected. 

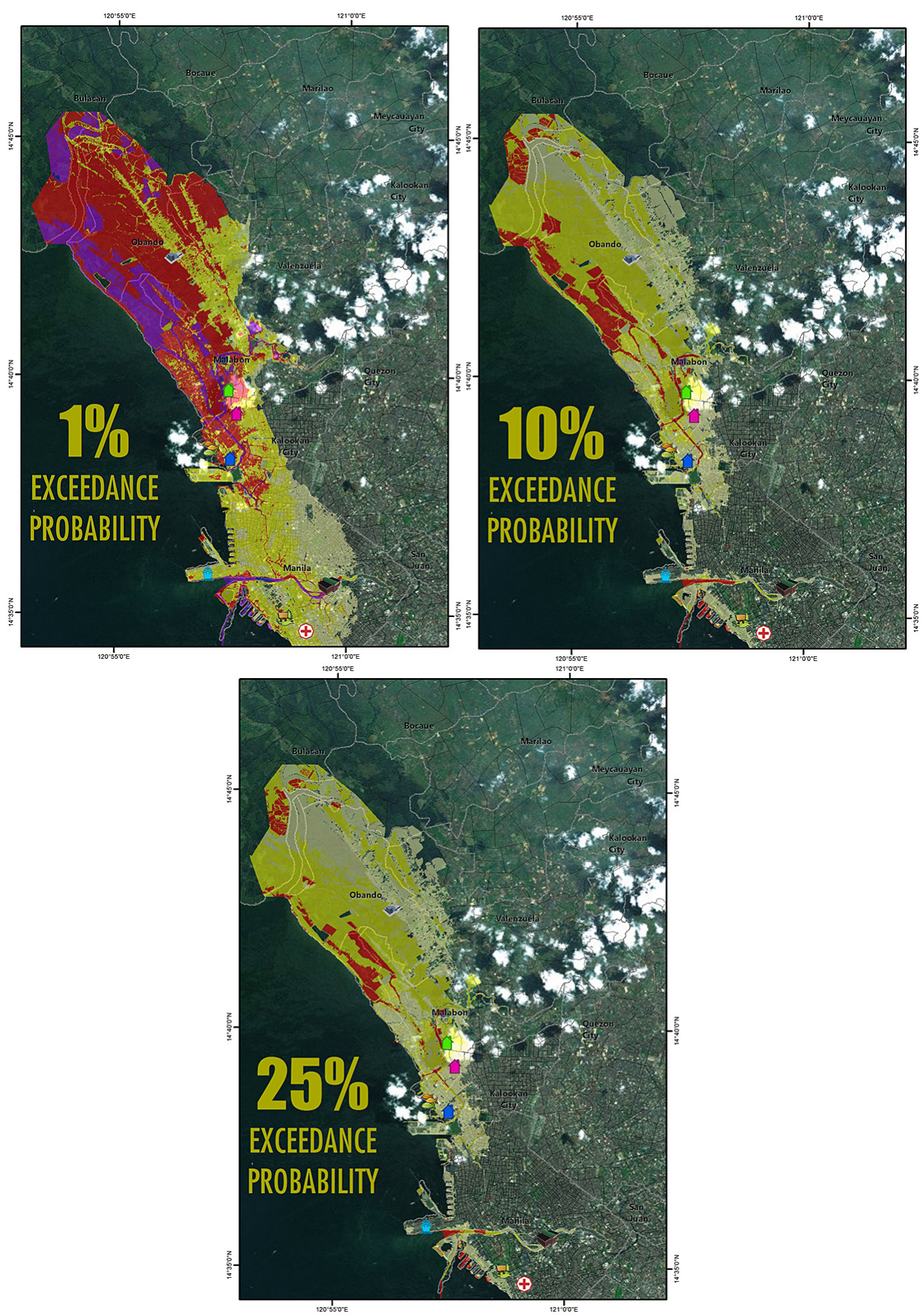

Figure 9. Storm surge inundation maps for PSWS 1 (please refer to Fig. 12 for the legend). 

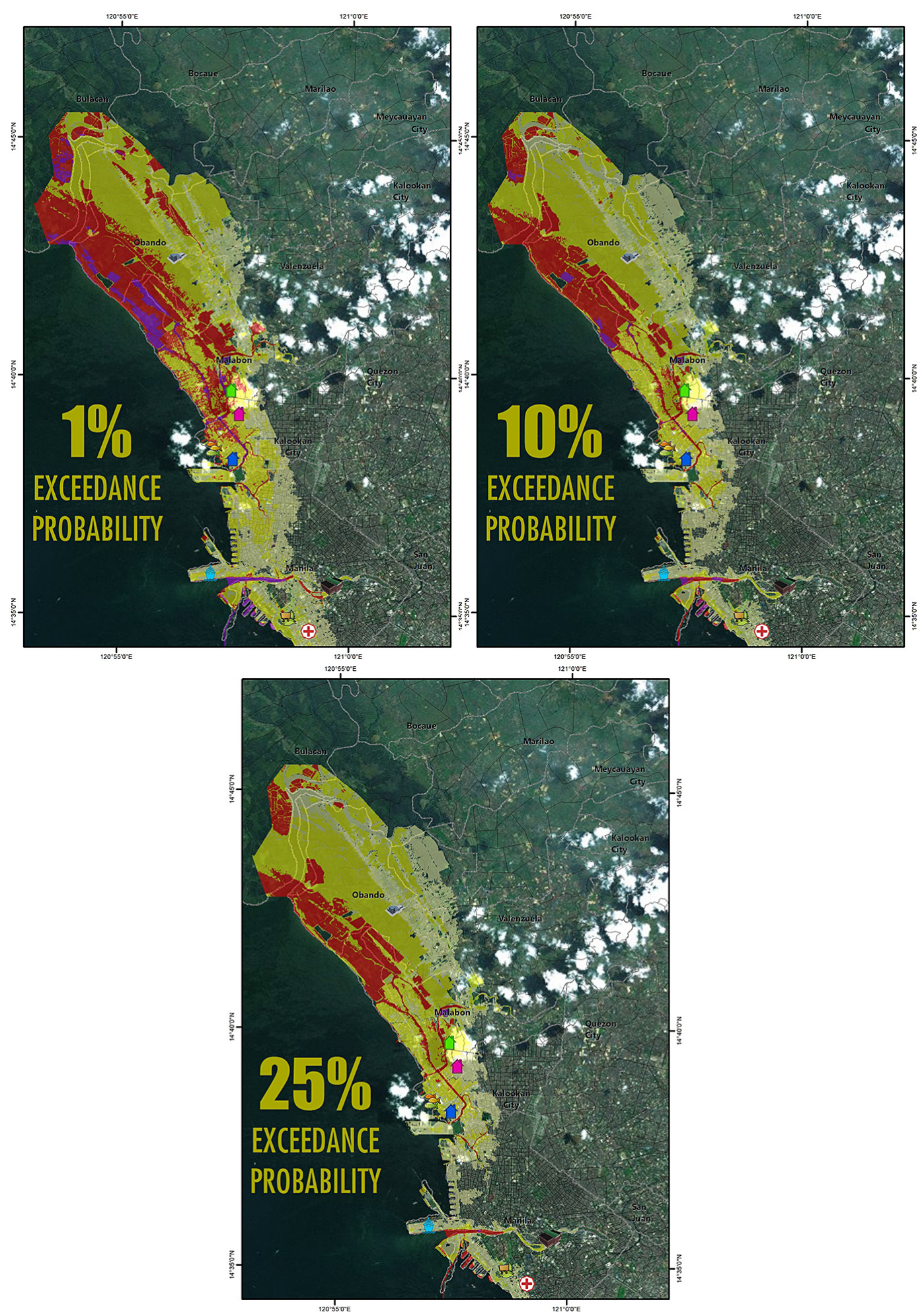

Figure 10. Storm surge inundation maps for PSWS 2 (please refer to Fig. 12 for the legend). 

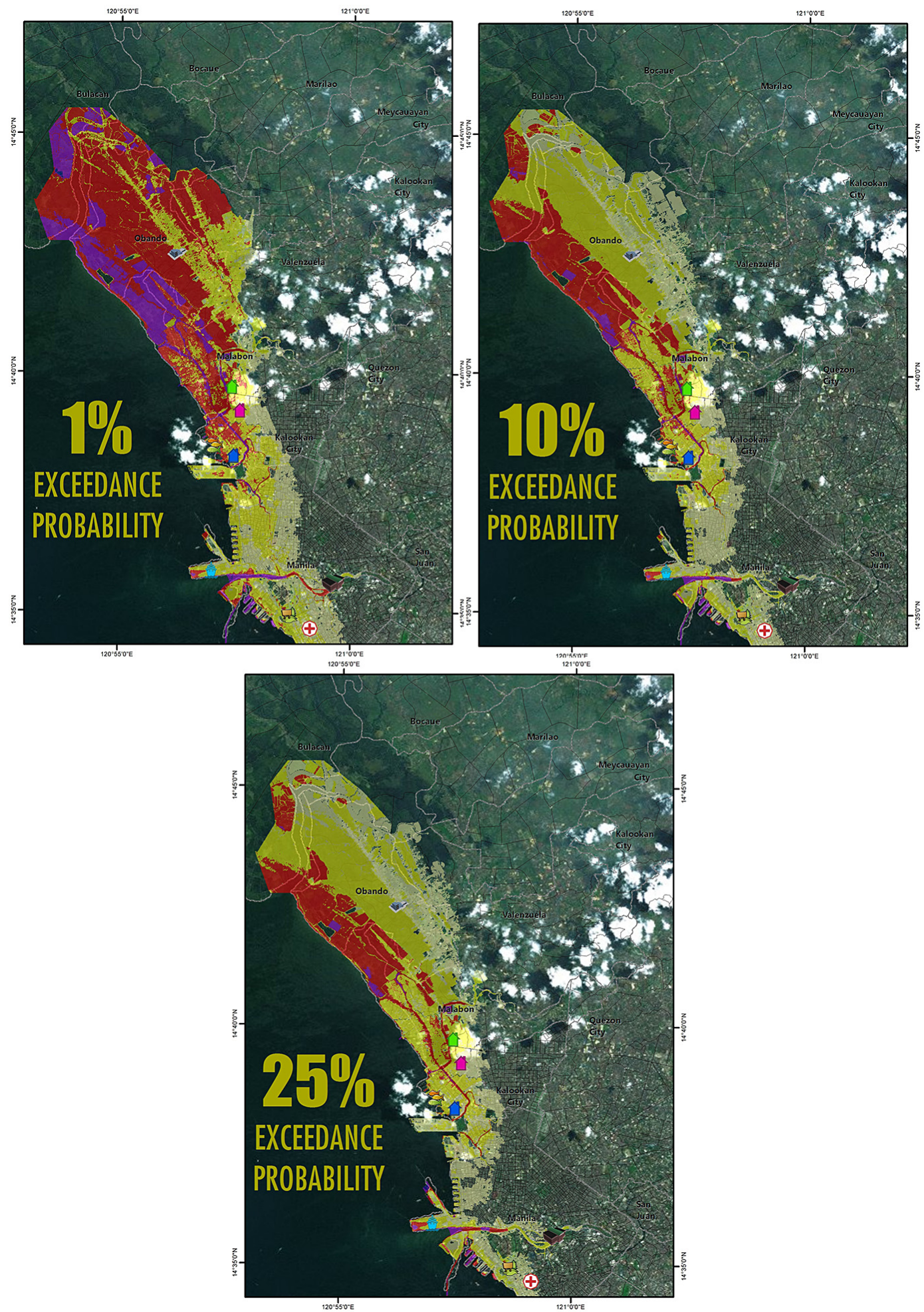

Figure 11. Storm surge inundation maps for PSWS 3 (please refer to Fig. 12 for the legend). 

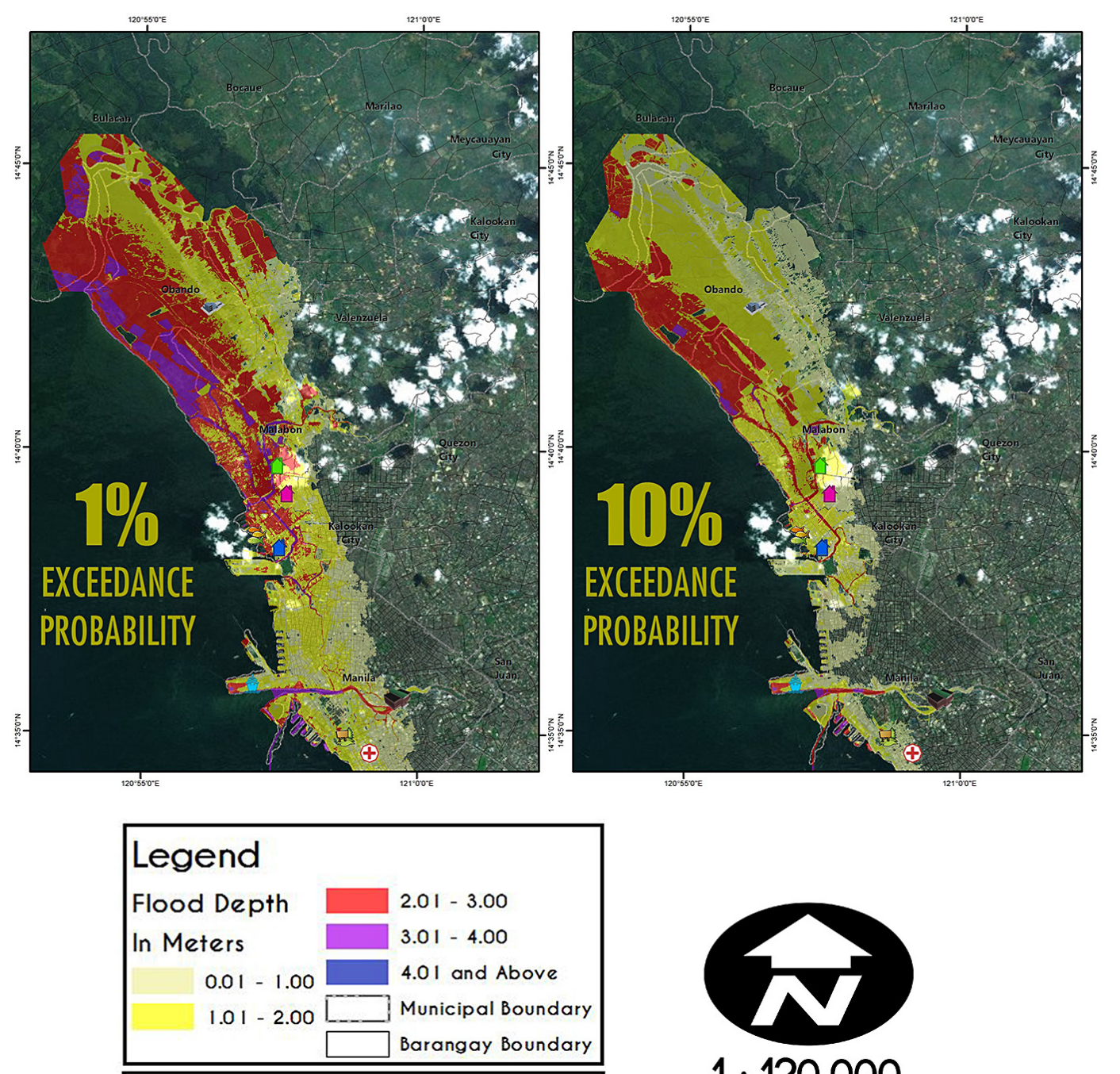

\begin{tabular}{|c|c|}
\hline 20 & Rizal Park \\
\hline & Manila Port \\
\hline$\Leftrightarrow$ & Navotas Fish Port \\
\hline & Malacanang Palace \\
\hline$\Leftrightarrow$ & Obando Town Hall \\
\hline 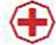 & Philippine General Hospital \\
\hline$\widehat{\imath}$ & Barangay Longos, Malabon \\
\hline 亿 & Barangay North Bay Blvd. South, Navotas \\
\hline U & Barangay Tonsuya, Malabon \\
\hline
\end{tabular}
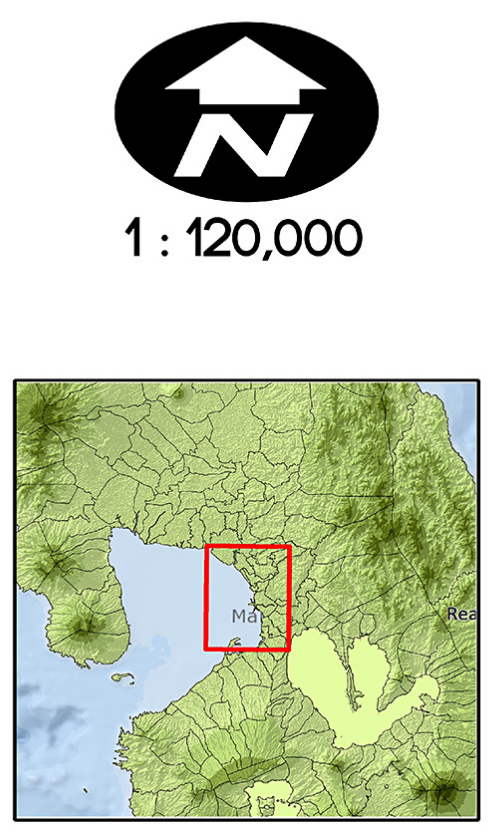

Figure 12. Storm surge inundation maps for PSWS 4 (with legend). 


\begin{tabular}{|c|c|c|c|c|c|c|c|c|c|c|c|}
\hline \multirow[b]{2}{*}{ Location } & \multicolumn{3}{|c|}{ PSWS1 } & \multicolumn{3}{|c|}{ PSWS2 } & \multicolumn{3}{|c|}{ PSWS3 } & \multicolumn{2}{|c|}{ PSWS4 } \\
\hline & 1 & 10 & 25 & 1 & 10 & 25 & 1 & 10 & 25 & 1 & 10 \\
\hline Philippine General Hospital & 1.07 & 0 & 0 & 0.18 & 0 & 0 & 0.35 & 0.27 & 0 & 0.78 & 0 \\
\hline Malacanang Palace & 1.06 & 0 & 0 & 0 & 0 & 0 & 0 & 0 & 0 & 0.65 & 0 \\
\hline Navotas Fishport Complex & 2.90 & 1.82 & 1.51 & 2.68 & 2.39 & 2.17 & 3.21 & 2.63 & 2.41 & 2.90 & 2.34 \\
\hline Port of Manila & 2.24 & 0.81 & 0.47 & 1.46 & 1.43 & 1.23 & 3.52 & 3.38 & 3.32 & 3.31 & 3.26 \\
\hline Barangay North Bay Blvd. South, Navotas & 2.43 & 1.35 & 1.09 & 2.21 & 1.84 & 1.60 & 2.52 & 2.08 & 1.77 & 2.54 & 1.82 \\
\hline Barangay Tonsuya, Malabon & 2.94 & 1.58 & 1.30 & 2.19 & 1.81 & 1.70 & 2.14 & 1.90 & 1.73 & 2.47 & 1.73 \\
\hline Barangay Longos, Malabon & 1.97 & 1.07 & 0.80 & 1.25 & 0.93 & 0.81 & 1.25 & 1.02 & 0.86 & 2.08 & 1.16 \\
\hline Barangay San Isidro, Makati & 0.68 & 0.60 & 0 & 0 & 0 & 0 & 0 & 0 & 0 & 0 & 0 \\
\hline Barangay Bangkal, Makati & 2.26 & 1.35 & 0 & 0 & 0 & 0 & 0 & 0 & 0 & 0 & 0 \\
\hline
\end{tabular}

Figure 13. Flood depth values for the selected points of interest.

\section{Conclusions}

The inundation maps show the areas in Metro Manila that are vulnerable to storm surges. These maps can help local government units (LGUs) to improve planning of building structures based on the nature of occupancy and assigned probability of exceedance. These maps can determine the areas where critical facilities such as evacuation centers, hospitals, fire stations, and police stations should be built. These facilities must also be given consideration prior to its construction and should not be built in storm surge inundated areas. However, if a facility must be built in a vulnerable area, it must be built with a higher level of protection. Additionally, these maps will help LGUs assess whether structures exist need further retrofitting.

These maps will also help LGUs implement appropriate countermeasures when a tropical cyclone is expected and a PSWS is raised in their locality. This will give LGUs sufficient time to prepare for the incoming tropical cyclone and plan for the necessary measures to prevent loss of lives, injuries, and damages to properties.

Furthermore, these maps will help LGUs develop risksensitive land use plans, disaster mitigation and preparedness plans, and vulnerability assessments.

Edited by: N. Kerle

Reviewed by: three anonymous referees

\section{References}

Association of Structural Engineers of the Philippines (ASEP): National Structural Code of the Philippines (NSCP) Volume I: Buildings, Towers and Other Vertical Structures, 6th Edn., Association of Structural Engineers of the Philippines, Inc. (ASEP), Quezon City, 5-6, 2010.

Box, G. E. P. and Jenkins, G. M.: Time Series Analysis: Forecasting and Control, 2nd Edn., Holden-Day, San Francisco, CA, 575 pp., 1976.

Dasgupta, S., Laplante, B., Murray, S., and Wheeler, D.: Climate change and the future impacts of storm-surge disasters in developing countries, CGD Working Paper 182, Center for Global Development, Washington, D.C., http://www.cgdev.org/content/ publications/detail/1422836 (last access: 19 February 2015), 2009.

FLO-2D Software: www.FLO-2D.com, last access: 19 February 2015.

Grossi, P. and Kunreuther, H. (Eds.): Catastrophe Modeling: A New Approach to Managing Risk, Huebner International Series on Risk, Insurance and Economic Security, vol. 25, Springer, New York, NY, 252 pp., doi:10.1007/b100669, 2005.

Higaki, M.: A Guide to JMA Storm Surge Model, in: Fourth Regional Workshop on Storm Surge and Wave Forecasting, Office of Marine Prediction, Global Environment and Marine Department, Japan Meteorological Agency, Tokyo, 2006.

Lynge, B., Hjelmervik, K., and Gjevik, B.: Storm surge and tidal interaction in the Tjeldsund channel, northern Norway, Ocean Dynam., 63, 723-739, doi:10.1007/s10236-013-0625-1, 2013.

McGranahan, G., Balk, D., and Anderson, B.: The rising tide: assessing the risks of climate change and human settlements in low elevation coastal zones, Environment and Urbanization, 19, 1737, doi:10.1177/0956247807076960, 2007.

National Oceanic and Atmospheric Administration: Understanding the "Probability of Exceedance" Forecast Graphs for Temperature and Precipitation, available at: http://www.cpc.ncep.noaa. gov/ (last access: 19 February 2015), 2012.

NOAA, National Hurricane Center (Storm Surge Resources): http: //www.nhc.noaa.gov (last access: 19 February 2015), 2013.

PAGASA: Current Climate and Observed Trends, http://pagasa.dost.gov.ph/ climate-agromet/climate-change-in-the-philippines/

116-climate-change-in-the-philippines/

594-current-climate-and-observed-trends (last access: 19 February 2015), 2014a.

PAGASA: The Philippine Public Storm Warning Signals, http:// pagasa.dost.gov.ph/learning-tools/public-storm-warning-signal (last access: 19 February 2015), 2014 b.

U.S. Indian Ocean Tsunami Warning System Program (US IOTWS): Tsunami Warning Center Reference Guide supported by the United States Agency for International Development and partners, Bangkok, Thailand, 311 pp., 2007.

Velleman, P. F. and Hoaglin, D. C.: Applications, basics, and computing of exploratory data analysis, Duxbury Press, Belmont, CA, 354 pp., 1981.

WXTide32: Tides and Currents for Win9x/NT, available at: www. wxtide32.com, last access: 19 February 2015. 